\title{
THE TASK OF A CULTURAL RESEARCHER: TELLING THE STORY OF SIBERIAN ESTONIANS
}

\author{
Anu Korb \\ Senior Research Fellow \\ Estonian Folklore Archives \\ Estonian Literary Museum, Estonia \\ Email:anu.korb@folklore.ee
}

\begin{abstract}
This article analyses the roles of a folklore researcher and the media in introducing the Siberian Estonian communities to the Estonian public after Estonia regained independence. With the restoration of the Republic of Estonia in 1991, the Estonians in Siberia, who had previously lived in the Soviet Union as Estonian Estonians, suddenly became so-called "foreign Estonians".

Since 1991, the Estonian communities in Siberia have been in the focus of collecting and research at the Estonian Folklore Archives (EFA), and 16 field trips were carried out in the period of 1991-2013. When we began our fieldwork, I realised that for Estonians Siberia was primarily associated with cold and wilderness, the deportations of the 1940s and prison camps. In the 1990s, the Republic of Estonia did not do much to support its compatriots in Siberia.

For the EFA, the inevitable side task to collecting and researching the folk culture of Estonians in Siberia was to inform and educate the general public in Estonia. Through the media we had a possibility to introduce and in some ways rehabilitate the Estonians in Siberia.

In the first decade of the twenty-first century, Estonians in Siberia became the focus of the general public in Estonia, prompting further increase in media coverage.
\end{abstract}

Keywords: collective memory, fieldwork, media, Siberian Estonians

\section{THE EARLIEST REPORTS OF ESTONIANS IN SIBERIA}

In the summer of 1991, the expedition group of the Estonian Folklore Archives (EFA) started fieldwork in various Estonian communities in Siberia. I vaguely sensed the colossal amount of work - an opportunity to explore an old-fashioned tradition. 
When I arrived in Estonia after the first fieldwork trip and shared my travel impressions, I realised that for Estonians Siberia was primarily associated with cold and wilderness, the deportations of the 1940s and prison camps. There was a lack of awareness about the Estonians who had emigrated there in the late nineteenth and early twentieth centuries, and about the ones who were deported there during the tsarist rule.

However, folklorists were not the first ones who brought information about Siberian Estonians to the motherland. Already a century earlier - in the late nineteenth and early twentieth centuries, several articles on Estonian settlements were published in the Estonian and Russian press. By the early twentieth century, the first descriptive overviews had been published by Jüri Meomuttel (1900) and August Nigol (1918). During the period when Estonia was annexed to the Soviet Union, the first scientific trips to the Siberian Estonians took place. In the summer of 1965, Igor Tõnurist travelled to Verkhniy (Upper) Suetuk and Verkhnyaya (Upper) Bulanka villages in Krasnoyarsk kray as an ethnography student at the University of Moscow (Tõnurist 1966). In the summer of 1975, an expedition of young scientists of the Estonian Academy of Sciences ${ }^{1}$ was undertaken, but little is known to the public about the collected data and research results. In the 1980s, linguists Jüri Viikberg and Lembit Vaba brought more information about the fellow countrymen by making trips to Estonian communities in Siberia (see, e.g., Viikberg \& Vaba 1984; Viikberg 1988, 1997) and Mare Piho and her colleagues by making trips to Siberian Setos (Piho 2002).

To some extent, there are materials about Siberian Estonians in Estonian archives and museums, for example, at the Estonian National Museum, the National Archives of Estonia, the Estonian History Museum, ${ }^{2}$ the archives of the Estonian Academy of Sciences, ${ }^{3}$ etc.

Knowledge of Estonians and the Estonian villages in Siberia can also be obtained from people whose ancestors once migrated to Siberia, but, for various reasons, they or their descendants have returned to Estonia. The first major wave of Estonians returning from Siberia is related to the formation of the Republic of Estonia in 1918 and the subsequent choice of nationality (Valitsusasutised 1934: 210). More Estonians from Siberia came back to Estonia during the Second World War and during the post-war period when Estonia was annexed to the Soviet Union.

Siberian Estonians were also transferred to Estonia by the Soviet and party functionaries, which resulted in tensions with homeland Estonians and damaged the reputation of Estonians in Russia for decades to come (Kulu 1997: 132; Jürgenson 2015: 43). 
In general terms, the return of Siberian Estonians can be compared to the tentative waves of immigration to Estonia. The immigration inflow became the most intense immediately after the Second World War; the reasons for expatriation were often political and ideological in these days. Due to the industrialization of the country in the period from the mid-1960s to the late 1970 s, it was done largely on the initiative of enterprises as indirectly guided migration. Later, migration for personal reasons began to prevail. Immigration decreased concurrently with Estonia's becoming an independent country (Tammaru 1999: 17-18).

\section{BEFORE THE RESTORATION OF THE REPUBLIC OF ESTONIA}

After the restoration of the Republic of Estonia in 1991, Estonians living in Estonia started to express active interest towards their compatriots in the Western countries, since the communication had been seriously hindered during the period of the Soviet rule. But the Estonians in Siberia and elsewhere in Russia, who had previously lived in the Soviet Union as Estonian Estonians, suddenly became so-called "foreign Estonians".

Back in the homeland, the repatriated Siberian Estonians, like Estonians born in Russia in general, experienced ostracizing due to differences in the cultural background, customs and traditions, but also because of prejudices. The negative image of Estonians returning from Siberia was largely due to the fact that the Soviet state directed the Estonians born and raised in Siberia to build Soviet order in Estonia, which contradicted to the good old Estonian order (Jürgenson 2015: 43). Thus, for decades they tried to disclose their origin from the general public.

After the restoration of the Republic of Estonia, Siberian Estonians felt that their collective history deserved rehabilitation as well. They acknowledged the need to make these memories publicly known.

In the 1980s, memory politics in Estonia was based on the idea of legal and historical continuity: there was an aspiration to restore everything that the Soviet period had destroyed or destined for oblivion (Pettai 2007: 2010). Memory is essential in raising awareness and recognition of identity; how and what we remember is of key importance (Kõresaar 2005: 10). In connection with the so-called second national awakening, interest in biographies and biographical experiences had arisen in Estonia (Kõresaar 2003: 63). Memoirs that have been published in large numbers in Estonia over the past few decades serve as if to balance the silent era in-between. 
In the years 1980-1990, the Estonian public had no greater interest in Estonians living in Siberia and elsewhere in Russia. At the same time, ties between Siberian Estonians and the Estonians in the motherland were not completely broken. On the initiative of the Society of Soviet Union Estonians (Liidu Eestlaste Selts) ${ }^{4}$, operating in Estonia at that time, a delegation including members of the folklore group Leegajus participated in the 140th anniversary of the Verkhniy Suetuk village (Krasnoyarsk kray) in the summer of 1990. Based on the visit to Siberia, the Estonian Radio produced broadcasts that gave an overview to interested parties about the life of Siberian Estonians. ${ }^{5}$ Around Midsummer Day in 1991 (midsummer is celebrated in the area according to the Old Style or Julian calendar), a month before the fieldwork organized by the Estonian Folklore Archives, a delegation from Estonia, led by Edgar Savisaar ${ }^{6}$, and also a Lutheran pastor from Estonia, visited the same village.

\section{ESTONIAN COMMUNITIES IN SIBERIA IN THE LAST DECADE OF THE TWENTIETH CENTURY}

In the period between 1991 and 2013, I visited the Siberian Estonians' communities, intending to find all the existing ones and to work there as a folklore collector. As a folklorist, I became more interested in the Estonians who lived compactly in villages, and whose fascinating cultural heritage captivated me.

According to the 1989 census in Russia, there were 17,000 Estonians living in Siberia. This figure includes the ones who lived in large cities, in Russian villages, and elsewhere. In the course of our fieldwork in Siberian rural areas (from Omsk oblast to Krasnoyarsk kray) we found about 40 Estonian communities with a population ranging between 25 and 300, with the majority of population having reached a respectable age. Relatively few villages were left where Estonian was spoken, with Estonians generally constituting just one ethnic segment of a multi-ethnic village.

There were Siberian Estonians' villages where little was known about life in Estonia and contacts with the relatives living in Estonia were sparse or broken (e.g. Ryzhkovo, Nikolayevka, Khaydak), yet many Siberian villages had had close ties with Estonia during the Soviet era (e.g. Verkhniy Suetuk, Berezovka, Zolotaya Niva).

After the introduction of the visa regime (in 1993) between the Republic of Estonia and the Russian Federation, Siberian Estonians, who used to keep in touch with their relatives and visit one another, felt cut off from their relatives in the homeland, owing to the economic recession and the complicated visa 
process. Remaining in the sphere of influence of the Russian media, Estonians in Siberia were nearly completely disconnected from information about Estonia.

In the 1990s, Estonians in Siberia fell also into cultural isolation. It became impossible to subscribe to Estonian newspapers, magazines, and books. In the Soviet period anyone who wished so, among others the village libraries in Siberia, could freely subscribe to newspapers and magazines published in Soviet Estonia.

Soviet national policy and practices related to it have changed over time. Initially, after the establishment of Soviet power, national-language administration was favoured. In areas where the ethnic minority accounted for twothirds of the total population, national village soviets were formed. People in these areas received the necessary information in their mother tongue. A great deal of attention was paid to fighting against religion, but at the same time native-language education, club activities, and the like were developed. For the first 20 years, cultural rights for the diaspora were also guaranteed (Slezkine 2012: 120, 126-128). Between 1937 and 1938, native-language education was banned and national schools were closed (Roemmich 1978: 42). Siberian Estonians consider terminating their Estonian schooling as an important loss of identity. Transition to school education in Russian also led to an increase in mixed marriages.

The policy of assimilation is pursued where the majority seeks to reduce the minority's group solidarity and identification with their group by reducing laws of society and cultural infrastructure. As noted by Finnish researcher Karmela Liebkind (1988: 32-33), minorities were left with only the possibility of leaving behind a museological imprint. In the Soviet period, fostering ethnic culture was in a way facilitated by district-wide or even province-wide folklore festivals and events celebrating the friendship of nations, etc., regardless of their political colouring, as at these events singing songs of different peoples in their ethnic language was obligatory (see Olson 2004). Occasionally, also meetings of Estonians from the region's villages were held; for example, in 1989 the Estonians of Tsvetnopolye, Orlovka, Zolotaya Niva and Ryzhkovo villages in the Omsk oblast celebrated Midsummer Day in Tsvetnopolye. In the 1990s, folk ensembles were still active in seven villages: Zolotaya Niva, Estonka and Tsvetnopolye (Omsk oblast), Oravka (Novosibirsk oblast), Berezovka (Tomsk oblast), Yuryevka (Kemerovo oblast), and Khaydak (Krasnoyarsk kray). The majority of the members in these folk groups, however, were already of advanced age. Due to the economic crisis, the performance possibilities of the folklore groups were reduced.

In these years, the village of Verkhniy Suetuk (founded in 1850), which is known as the largest Estonian settlement in Siberia, certainly received more 
attention from Estonians in the homeland as compared to other villages in Siberia. There is a brass band, established in 1901 and thus the oldest in the area, and the oldest existing Lutheran church building in the village. In the 1990s, the church of Suetuk, which had been used as a grain storage and a club house in the meantime, was re-established as an ecclesiastical building. Since 1990, once or twice a year, a pastor from Estonia has been visiting the congregation. ${ }^{7}$

It is typical of Estonian village communities in Siberia that there are very few people who have written down their own village or family history, not to mention recording oral tradition (such as songs, narratives, ritual accounts, etc.). Thus, all hope in this matter is on outsiders - folklore collectors and researchers. A surge in the national self-consciousness of the small ethnic groups in Russia has strengthened the interest of Estonians living there in their roots and ancestral traditions, both on the individual and community level. More active people have searched the archives for information about the village history, their repressed relatives, and marked the locations of the former village sites; for example, people from the former Estono-Semenovka village in Novosibirsk oblast erected a monument at the site of the destroyed village to commemorate the founders of the village, the people repressed in the 1930s, and the villagers who were killed in the Second World War. Some village museums have been founded, for example in Berezovka (Tomsk oblast), Zolotaya Niva (Omsk oblast), and Khaydak (Krasnoyarsk kray) ${ }^{8}$. Many Siberian Estonian villages asked us to return copies of our recordings to the community so that the younger generation could learn more about the lives and traditions of their ancestors.

There are new opportunities in Krasnoyarsk to participate in Estonian culture as an Estonian society was founded there in 1992 (until today, the only Estonian society in Siberia).

Following the collapse of the Soviet Union, emigration to Finland and especially to Germany became acutely topical in Russia. Lutherans living in Siberia (e.g., Estonians, Latvians, Germans, and Finns) had lived close to each other ever since the founding of the settlements, partly in villages of mixed ethnicity. In the 1990s, Germany offered effective assistance to expatriates wishing to return to Germany. In Siberia, people saw us, folklorists, as representatives of the Estonian state and inquired from us why Estonia, unlike Germany, did not invite its former citizens to return. The situations are not entirely comparable because Estonians who wished to return to homeland from Siberia during the Soviet period, generally did so, ${ }^{9}$ whereas Germans in Siberia did not have free access to their historical homeland at that time.

In the 1990s, many Estonian villages in Siberia celebrated the centenary of their foundation and the celebrations usually helped to capture the attention of the local administration and receive financial support to organize these 
events. The events were broadcast on the Russian media. Unfortunately, no representatives of Estonia were usually present. Only in 2000 representatives of the Estonian Embassy in Moscow arrived at the centenary celebrations of the village of Khaydak in Krasnoyarsk kray.

\section{PRESS COVERAGE OF SIBERIAN ESTONIANS IN 1991-2000}

The press is primarily associated with the event and the news. Through the event, the press reconstructs reality. Background information accompanies the text that becomes public (Treufeldt 2012: 27,44). The statements made in the text are based on certain assumptions or prejudices which make it possible to present facts. It can be said that journalistic text works with the effective help of the public, and both the press and the public are involved in the interpretation. The press cannot present texts that do not contain the knowledge to understand it. When journalists describe the present, they often describe the past as well (Zelizer 2008: 81). Michael Schudson (1997: 3-7), who studies the history of journalism, emphasizes that current events and beliefs lead us to explore the past, as understanding the past shapes our understanding of the present. The perceived role of journalism has been to influence the public perception of time and mediate historical memory. Journalists mediate reality from their subjective perspective, but they are never completely free to publicize their personal views and always depend on the institutional background (Treufeldt 2012: 48). Next to journalists, the stories with historical context are influenced by biographical sources, i.e., immediate witnesses of the event; the official source, i.e., politicians and administrative officials; academic sources, i.e., researchers; and cultural sources, i.e., artists, writers, etc. (Zandberg 2010: 18).

In the 1990s, the Republic of Estonia did not do much to support its compatriots in Siberia. Madis Hint published a critical article in the newspaper Eesti Päevaleht (Estonian Daily) (Hint 1998: 5), titled "Siberi eestlased on maetud unustusse" (Siberian Estonians have fallen into oblivion), in which Estonian officials were reproached for neglecting their fellow countrymen in Siberia.

Although the media coverage of the fieldwork in Siberia reached the public through the Estonian Folklore Archives, Siberian Estonians did not receive much interest in the newly restored Republic of Estonia. It is also worth mentioning that when we had returned from our first Siberian fieldwork trip, a journalist from the magazine Liivimaa Kroonika (Livonian Chronicles) approached me and was interested to know what Siberian Estonians thought of Edgar Savisaar (Haug 1991). Thus, the media was not interested in the life of the Siberian Estonians at that time, but rather in what they thought about an Estonian prominent. 
In Estonia in the 1990s, mainly editors of cultural periodicals and media programmes evinced interest in Siberian Estonians' communities as representatives of a preserved archaic culture. We had a chance to present the Estonians' communities in Siberia and their folklore (beliefs, folktales, songs, etc.) in Estonian Radio cultural programme "Esivanemate vaimuvara" (The spiritual treasures of our ancestors, 1989-1994). Through the digital archives of the Estonian Radio, 76 broadcasts of this series can be listened to, five of which introduce the Siberian Estonian communities and their traditions. ${ }^{10}$ The video footages about the village of Berezovka in Tomsk oblast (1993) and Tsvetnopolye and Tara area in Omsk oblast (1996), which were shown on Estonian television news bulletin "Teateid tegelikkusest" (Messages from the reality) deserved more attention. Furthermore, history minutes in the analytical-commenting weekend show on Estonian Television, called "Brauser" (Browser) (1999), were also well received. In this series, we introduced emigration to Siberia based on our fieldwork. ${ }^{11}$ In the folk culture programme "Paar palvid: Siberi eestlased" (A couple of prayers: Siberian Estonians) (1993), I invited people who had returned from Siberia to Estonia to share their knowledge about life in Siberia. ${ }^{12}$

In Russia the regional newspapers started to publish an increasing number of articles on the life and situation of compactly living ethnic minorities. Siberian Estonian communities also captured journalists' attention. For example, on 19 November 1998, in the newspaper Omski Vestnik (Omsk Gazette), in the section about multinational Siberia, there was an article about Lileika and Estonka Estonians (Gonoshilov 1998: 8). The reader was given an overview of the establishment of the villages.

Some of the texts in the Siberian regional newspapers were inspired by the fieldwork of the Estonian Folklore Archives in Siberia. On 19 May 1997, Azovo newspaper Ihre Zeitung in the German national district of Omsk oblast published Arthur Jordan's writing “Взгляд из Цветнополье” (A glimpse of Tsvetnopolye) (1997: 4). The same newspaper's culture column wrote about the Estonian Folklore Archive's fieldwork in the region in 1996 and in 1997 as well as about the presentation of the book Taaru-tagused ja stepiasukad: Eesti asundused IV (Behind Tara and in the steppes: Estonian settlements IV), compiled by Anu Korb, in Tsvetnopolye village community centre (Kistner 2001: 5).

In 1999, Peterburi Teataja (St. Petersburg Gazette, founded in 1908), the only newspaper published by Estonians in Russia, started to be issued again. The Estonian-language newspaper founded in St. Petersburg, the capital of the Russian Empire, played an important role in the cultural life and struggle of Estonians both at home and among Estonians in Russia. It was published in the period of 1908-1918 as a weekly newspaper and later as a daily newspaper..$^{13}$ Jüri Trei, who started working as a consul in St. Petersburg in 1999 
and launched a project about Estonians in St. Petersburg, played an important role in establishing the newspaper. The St. Petersburg Gazette is published quarterly, with a circulation of 700-900 copies. The newspaper covers the activities of Estonians in St. Petersburg and elsewhere in Russia. ${ }^{14}$ Articles about events in the Estonian communities in Siberia are also published there.

In Estonia, the media interest towards Siberian Estonians increased after the interdisciplinary conference under the heading "Eesti kultuur võorrsil: Asundused" (Estonian Culture Abroad: Settlements) was held at the Estonian Literary Museum in September 1997, during which we also opened an exhibition about Estonian villages in Siberia (compiled by Mari-Ann Remmel). The conference, organized by the Estonian Folklore Archives, concluded with a roundtable discussion, where scholars who were engaged in the research related to Estonians in Siberia addressed issues concerned with assisting Estonians living in Russia and problems related to return migration (Korb 1997). The idea of applying for money from the European Union to call back the Estonians living in Russia and to establish a Russian Estonians' village in Pajusi near Jõgeva, Estonia, was also on the agenda. The initiator of the idea was Ants Paju, an adviser to the then Ministry of Transport and Communications. Newspapers Postimees (The Courier), Eesti Päevaleht (Estonian Daily), Õhtuleht (Evening Paper), Kodumaa (Homeland), and others highlighted the issue and the problems related to the planned establishment of the village. The researchers who had conducted fieldwork in Siberia believed that it would be wise to scatter the returning persons instead of placing them in one village, which could likely be prone to isolation. It was suggested that comprehensive cultural exchanges with settlements should be encouraged, visa procedures should be simplified, and those wishing to settle in Estonia should be assisted. To ensure the preservation of Estonian culture in Siberia, the participants of the conference addressed an appeal to the Prime Minister of the Republic of Estonia.

Later the exhibition about Estonian villages in Siberia was displayed at the Väike-Maarja Museum, Kilpkonna Gallery in Viljandi, and the National Library in Tallinn, and the opening of the exhibition also attracted some media attention.

Thus, in addition to collecting folklore, and the research and popularization activities that emerged from it, the Estonian Folklore Archives' fieldwork group became a kind of a link between homeland Estonians and Siberian Estonians in the last decade of the twentieth century. 


\section{SHARING THE INFORMATION COLLECTED DURING FIELD TRIPS}

We wanted to share the information that we had gathered about the life of Estonians in Siberia with the general public and at the same time value the heritage of Siberian Estonian communities.

A folklore collector and researcher has the power to make the voice of an individual heard to the public in the form of published books, documentaries, exhibitions, websites, etc. However, the truths of cultural descriptions are always incomplete, imperfect, and related to a point of view (Clifford 1986: 7). Relying on the experience of many researchers, including myself, I argue that informants are usually interested in making the material they contributed reach the general public and also back to the community.

Since 1995, I have compiled a series of anthologies titled Eesti asundused (Estonian settlements). The first four volumes published in 1995-1999 focused on folklore, each book introducing the traditions (folktales, songs, games, customs, rituals, charms, etc.) that have survived in a specific region. I have maintained contacts with my informants also outside fieldwork and sent the published materials to the Estonian communities in Siberia. My informant network has greatly helped to improve and specify data about Siberian Estonians, and they also give feedback to my work.

Later on I compiled a CD anthology Siberi eestlaste laulud (Songs of Siberian Estonians) (2005) and, in cooperation with my colleague Andreas Kalkun, a multimedia publication Siberi setode laulud (Songs of Siberian Seto) (2012). The Siberian Estonians' songs were introduced, for example, in an Estonian Radio broadcast "Pärimuster" (Heritage pattern), and also elsewhere, and presented by many folklore groups (e.g., Untsakad, Trad Attack, etc.).

Since 2005 I have also been a contributing author to the Estonka website ${ }^{15}$, curated by Astrid Tuisk, and in cooperation with Kadri Viires and the Estonian Art Academy, I co-authored an exhibition under the heading "Siberi eestlased" (Estonians in Siberia) (2008), which was displayed in several places in Estonia, Russia, Canada, and the United States. The documentaries based on the material recorded during the field expeditions in Estonian communities in Siberia (Korjus 2005; Laiapea 2013) have been shown at film festivals and on national television.

From 2003 to 2017, we organized six popular family events under the heading "Venemaale veerenud" (Rolled to Russia) at the Estonian Literary Museum, where we presented to the interested parties Estonian villages, their life, and culture from the past to the present in different places of the Russian Empire. 
We focused on the visualization of the collected information by making the archives as visible as possible.

I also continued the series of anthologies about Estonian settlements. In 2004, I launched, in Estonia, a campaign for collecting village and life histories of Estonians in Russia, but the contributions included only a small number of tales by Siberia-born Estonians. Still, they were more than willing to tell me their stories. They found in me a confidante, a listener, and someone to record and thus perpetuate their tales. From the viewpoint of oral narrative history, personal contact with the informants and their living environment is considered one of the major advantages of interviewing (Pöysä 2009: 43).

Most of the material published in the book Siberi eestlaste elud ja lood: Eesti asundused $V$ (The lives and stories of Siberian Estonians: Estonian settlements V) (2010) was collected in the form of interviews carried out during 2003-2009. Of course, by far not all the interviews that I conducted found a place between the covers of the book, but all of them are stored at the Estonian Folklore Archives at the Estonian Literary Museum. The fact that my interviewees previously knew of my research into Siberian Estonians made the interviewing process somewhat smoother. The time of collecting the material - the first decade of the twenty-first century - was highly opportune for the work: there were still enough people left who could tell me about the past, there was an increased public interest in the Estonians in Siberia, and the topics that used to be viewed as taboo are nowadays being discussed more openly.

What does remembering depend on? Which are the factors that may cause the disruption of narrative lore? The knowledge and stories about ancestors, whom one has not seen with one's own eyes or who are no longer remembered because of the informants' youth, rely on the memory of previous generations. In terms of Estonians in Siberia, a decisive factor in the interruption of the oral narrative was the destruction of the traditional village life by the Soviet authorities: dekulakization, mandatory collectivization, and forcing people to move from farms into villages. In the 1930s, nearly all families suffered from repressions which were often accompanied by the confiscation of Estonian books and letters and photographs sent from the homeland. Between 1936 and 1938 followed the closing of Estonian schools and a ban on any social group activities. The injustice that nobody ever talked about in the Soviet period has become an important conversation topic in today's more liberal situation. Speaking about traumatic events may sometimes have a therapeutic effect. Each family has their own story of sorrow that, combined with others, will make up the shared traumatic experience of Estonians in Siberia.

An informant always makes a choice of what to tell and how to do it. Narratives also reflect people's moral disposition towards the world. A memoir 
can be viewed as a process, in the course of which a group's history is being reconstructed (Peltonen 1996: 27). During narration, the temporal distance from actual and/or experienced events generally contributes to the story's informative value (Kirss 2006: 633).

My aim was to assemble a collection of stories that would be an interesting read also for the people who have had no direct contact with Siberia. I employed the memories of Siberian Estonians to present as versatile picture of several generations of Siberians as possible, illustrating the text with ethnographic descriptions, popular healing methods, etc., and did my best to avoid overusing statistics and names. Next to oral interviews, I also made use of a few recollections written down by Siberian Estonians - these were texts that I had asked them to put down, not previously existing ones. Finnish researcher Satu Apo (1993) has introduced the concept of thematic writing. Thematicity indicates that the theme of a writing is always limited to a certain extent (Pöysä 2009: 41). But then interviews also concentrate on a particular topic. It seems to me that the meaning of a conveyed message is not dependent on whether the narrative is presented in oral or written form. Oral performance likewise relies on collective communal memory, often drawing on personal documents, photographs of family members and village life.

Portelli argues that oral narrative tradition itself is a way of expression that has developed under the influence of other oral and written genres; here the narrators and the researcher employ the topics and forms offered by personal experience narratives, folklore, and the media (Portelli 2000 [1998]).

Estonians in Siberia were sincerely happy about the publication of the book about the lives and stories of Siberian Estonians, and regarded it as the history of their community. The book also attracted the interest of an outgroup audience, offering them a chance to look in retrospect at the politically and economically difficult times from the perspective of Estonians in Siberia, and perhaps to better understand those Siberian Estonians who had decided to return to Estonia.

The book was also promoted by the media. For instance, Estonian historian Hillar Palamets introduced the life of Estonians in Siberia in a Radio 2 series "Ajalootund" (History class). Palamets used a selection of my texts to illustrate the key historical events (resettlement in the second half of the nineteenth century, the Bolshevik rule, the Russian Civil War, repressions, the Second World War), and although he informed me of his plans in advance, the final choice of texts for the radio programme remained his. This way, fragments of the stories from the book were broadcast in a very enjoyable, folk-like manner.

The book series Eesti asundused (Estonian settlements) was also used as background material for the documentary play "Jaanipäev" (Midsummer Day) 
(directed by Tõnn Lamp), which premiered at the Estonian Drama Theatre in the spring of 2018. The play is based on Mari-Liis Lill and Paavo Piik's trip to Verkhniy Suetuk village in Siberia in 2016 and the information gathered through interviews. Folklorists' work was used in the play primarily in the text of the introductory character Pärandi-Jüri (Heritage John), which provided viewers with first-hand information about Siberian Estonians: how their ancestors came to Siberia and what their customs and traditions were like. The play received a lively response from the audience, with a series of praising reviews in the media. It was described as a staging of "our biographies", telling about how Siberian Estonians remained Estonians, about their adaptation, attitudes, and traditions. Bringing the topic of Siberian Estonians before the audience was praised, as well as the work of the actors in depicting diverse characters. At the same time, there were some critical reviews (Herkül 2018), which criticized the play for its shallowness and superficiality.

Throughout the play, the audience had the opportunity to enter the Siberian Estonians' world, to get an idea of their opportunities to stay Estonians abroad, of their integration, attitudes, and traditions. For Siberian Estonians a story, either perpetuated in print or staged as a live performance (see, e.g., Carpenter 2011: 35), may represent the history of their family, their village, or more generally, the past of Estonians in Siberia. For the outsiders it is more of an opportunity to peek into an unknown world. Also, in published form the narrative texts are not final but are open to new interpretations.

\section{INCREASING ATTENTION ON SIBERIAN ESTONIANS}

At the turn of the century and after that, Estonians in Siberia became the focus of the general public in Estonia, prompting further increase in media coverage. Educational and cultural exchange intensified as well. With the financial support of the Ministry of Science and Education in Estonia and the Integration Foundation, organizing language and culture camps in Estonia for children of Estonian descent living in Russia was started in 2000.

Since 1992, young people from Finno-Ugric minorities have had the chance to study in Estonian higher education institutions with the support from the government of Estonia, whereas the state-financed study programmes targeted at Estonians living in Russia were initiated ten years later.

When the Estonian Ministry of Education sent Piret Toomet as the first Estonian teacher to Verkhniy Suetuk village for the school year 2000/2001, the event received wide coverage in the Estonian media. Along with numerous newspaper articles (see, e.g., Heinla 2000), Heini Drui made a film titled 
Siberi õpetaja (Teacher in Siberia) (2001), which captured the school year of Piret Toomet, who taught the mother tongue in this Estonian village in Siberia. The film was shown repeatedly on Estonian television (ETV). One movie review stated that Siberi opetaja is a documentary triumph. Dozens of interviews and descriptions cannot replace the camera eye that monitors events over a long period (Laasik 2001). The film also brought to the audience the everyday life of an Estonian village in Siberia.

The next teacher selected for the job was Airi Lauri, but her work in Siberia received far less recognition - the topic was no longer novel. Airi Lauri got married there and still lives in the village of Verkhniy Suetuk. Airi received media attention much later and for quite a tragic reason - a fire in her family house in the winter of 2018. The incident was reported as news as well as a request for help in several Estonian newspapers (Postimees, Õhtuleht, etc.).

The media also reported accidents in other Estonian villages in Siberia. Concerning a flood, Siberian Estonian village Narva (Krasnoyarsk kray) on the Mana River was mentioned (Käänik 2008). A fire accident in Estonka village in the Omsk oblast caused more controversy because it started as a result of negligent hay burning (see, e.g., Venemaal 2011). When a journalist has to write about an unfamiliar topic, he or she can use memoirs and the historical past as tools for story-telling. When communicating to the general public, one must always presume that the reality presented in the texts is shaped by a large number of factors. The commentators of the article had a lively discussion about who should help the Estonians, how Estonians had ended up in Siberia, and even if they could still be called Estonians.

Articles about the life of Estonian communities in Siberia began to appear in the press more frequently when Estonian journalist Jaanus Piirsalu started work as a correspondent of the newspaper Eesti Päevaleht in Moscow in 2007. Piirsalu started writing a column in the newspaper about Estonian and Seto villages in the territory of the former Soviet Union. The readers were asked to send him information about Siberian villages. Piirsalu himself repeatedly contacted me and other folklore collectors who had worked in Siberia to clarify some details related to the villages, to inquire about driving routes, and so on. In 2014 Piirsalu started work as a reporter for the newspaper Postimees and has published articles related to the living conditions in Siberian villages and the most prominent Estonians in Siberia.

After the Bronze Night ${ }^{16}$ in the spring of 2007, cultural cooperation was one of the few fields that was still encouraged. The first cultural cooperation projects that brought Estonians from the motherland to Siberia were based on personal relationships. For example, in the spring of 2002, the Estonian Drama Theatre's trip to a festival in Krasnoyarsk kray took place thanks to the personal relations 
of Director Tiit Lauri; the festival was organized by the Krasnoyarsk Pushkin Theatre. In addition to festival performances, the representatives of the Drama Theatre visited the Estonian school in Verkhniy Suetuk in the southern part of the kray and organized a collection of books for the village library and the Krasnoyarsk Estonian Society with the help of Estonian publishers. The trip was covered by a special broadcast by TV 3 (Eesti 2002).

In the spring of 2008, a framework agreement on cultural cooperation between the two countries was signed in Moscow and the tradition of organizing Estonian cultural days was restored. Andra Veidemann, the cultural attaché of the Estonian Embassy in Moscow at the time, provided information about Estonian communities in Siberia in the newspaper (Piirsalu 2008); she received most of the information from me.

Since the beginning of the twenty-first century, the employees of the Estonian Embassy in Moscow have increasingly asked me questions about various Estonian communities in Siberia. Information on the size, location, contacts, etc. of the communities has been requested. The embassy staff began to visit Siberian Estonian communities periodically. The visits were often related to some event important for the Siberian Estonians. In March 2010, I participated in the opening of the exhibition "Siberi eestlased" (Siberian Estonians) at the National Science Library of Krasnoyarsk. When the Estonian Society in Krasnoyarsk celebrated its 20th anniversary in April 2012, I and my colleague Andreas Kalkun had an opportunity to introduce during the festivities our anthology Siberi setode laulud (Songs of Siberian Seto). In May 2016, I participated in the embassy's visit to the Estonian villages of Berezovka and Liliengofka in Tomsk oblast (about the visit see: Suursaadik 2016).

The anniversaries of the Republic of Estonia have also given reason to travel to Siberia. In December 2008, days of culture dedicated to the 90th anniversary of the Republic of Estonia, with conferences, exhibitions, and concerts, took place in Tomsk (Heinla 2008: 28-29). The 100th anniversary of the Republic of Estonia was celebrated in May 2018 in Krasnoyarsk kray. The choice was logical, since the only Estonian Cultural Society in Siberia, chaired by Vera Oinets, operates in Krasnoyarsk. The society is comprised of people who were born in the Estonian villages in Minusinsk region and who speak the North-Estonian dialect, as well as those who live 100-200 km from Krasnoyarsk, speak Seto and Võro dialects and do not understand the written language that evolved on the basis of the North-Estonian dialect. Thus, members of the Krasnoyarsk Estonian Society find it difficult to use their mother tongue. However, linguists have noted that language is one of the most important symbols of group identity (Ryan 1979: 147, 149). 
Over time, Siberia began to be seen as an exotic travel destination. Many groups from Estonia have visited some Estonian villages during their travels. I have been receiving more and more inquiries about Estonian villages in Siberia. The most well-known are the " $4 \mathrm{x} 4$ group" of off-road travellers, who between 2011-2013 briefly visited Vambola and Berezovka in Tomsk oblast and Verkhniy Suetuk in Krasnoyarsk kray. The television screened a ten-episode series under the heading " $4 \times 4$. Magadan", and a travel guide was published based on the notes taken during the trip (Laisaar 2016).

Perhaps the best-known Estonian village in Siberia, Verkhniy Suetuk, has been widely documented on film in recent years, and the documentaries have been shown on national television (Drui 2001; Korjus 2005; Niglas 2011). A filmmaker's view of the village life is certainly quite different from that of the folklorist's or ethnologist's. Researchers of culture seek and find authentic old tradition in the villages, and observe the exiting changes brought about by the influence of the multicultural surroundings. Documentaries, of course, mostly focus on everyday life. Naturally, any representation remains partial and somewhat biased, so there is no objectivity in it.

\section{CONCLUSION}

After the restoration of the Republic of Estonia in 1991, when the Estonian Folklore Archives started fieldwork in the Estonian villages in Siberia, Estonians in Estonia had little knowledge of and not much interest in Estonians who lived in Siberia. Meanwhile, those interested had the opportunity to get acquainted with the overviews that had been published almost a century earlier and the information received from Estonian museums and archives in different time periods. Many Siberian Estonians who returned to Estonia tried to hide their Siberian origins during the Soviet era.

In the 1990s the Republic of Estonia did not do much to support its compatriots in Siberia. The ties between Siberian Estonians and those in the motherland were not completely broken, but for economic and political reasons, mutual communication was largely stalled.

It seems to me that the trips to collect folklore among Estonians in Siberia were particularly important following the restoration of independence in Estonia, the final decades of the twentieth century. We managed to record unique material, but perhaps even more important were the long-lasting relations that we established between Estonians in the homeland and in Siberia. I have personally tried to contribute by sending to the Estonian villages in Siberia publications and copies of the material collected from them. For the Estonian 
Folklore Archives, the inevitable side task to collecting and researching the folk culture of Estonians in Siberia was to inform and educate the general public in Estonia. We organized information days and exhibitions, created a website, and published popular-science publications. Many Estonians who were born and raised in Siberia and now live in Estonia, began to cooperate with me and share their family and village stories with the public. Through publications, articles, and events we tried to make Estonians realize that the majority of Siberian Estonians were ordinary rural people who had to suffer badly due to a totalitarian regime.

By the beginning of the twenty-first century, Siberian Estonians were much better known than they had been over a decade earlier. Changes also took place on the national level. The Estonian Ministry of Education and Research sent a teacher of the Estonian language and culture to Verkhniy Suetuk, the largest Estonian village in Siberia. Siberian Estonians were given the opportunity to study at Estonian universities with the support of the Republic of Estonia, and cultural exchange intensified. The Estonian Embassy in Moscow began to organize visits to various Estonian communities in Siberia. Over time, Siberia started to be seen as an exotic travel destination.

In Estonia in the 1990s, mainly editors of cultural periodicals and media programmes evinced interest towards Siberian Estonians' communities as representatives of a preserved archaic culture. Estonians in Siberia became the focus of interest of the general public in Estonia, prompting further increase in media coverage. Due to the growing interest, the media started to write more and more about Siberian Estonians.

The support of Estonia would not reach all the Estonian communities in Siberia. The reality is that Estonian population in Siberia has decreased rapidly in the past 20 years. There are, however, new opportunities in Krasnoyarsk, as an Estonian society was founded there.

\section{ACKNOWLEDGEMENTS}

The article was supported by the research grant of the Estonian Literary Museum EKM 8-2/20/2 and by the Centre of Excellence in Estonian Studies (TK 145) through the European Regional Development Fund. 


\section{NOTES}

1 Participants: Lembit Võime, Igor Tõnurist, Ülo Kaevats, Jaak Simm, and Arp Karm.

${ }^{2}$ Collection F 309: Eesti asundused Nõukogude Liidus (Estonian settlements in the Soviet Union).

3 Collection F 29: Viktor Maamägi's collection.

4 The society was established on 15 December 1988 and is today known by the name of East-Estonians' Society (Ida-Eestlaste Selts).

5 See https://arhiiv.err.ee/vaata/ulem-suetuk-soojad-tukid-ulem-suetuk-soojad-tukid-01, last accessed on 16 January 2020.

6 Estonian politician, Prime Minister in 1990-1992.

7 In 2007, the congregation was transferred under the Ingrian Evangelical Lutheran Church, but Estonians in Suetuk still look forward to the visits of the Estonian pastor.

8 All of the villages mentioned here have been established by migrants who were searching for better living conditions in Siberia. As the villages were mainly made up of people from one area, the language and customs persisted for a long time. Berezovka is dominated by Northern Estonians, Zolotaya Niva by people originating from Võru County, and Setos live in the village of Khaydak. Siberian Estonians generally identify themselves as Lutheran, while Siberian Setos are Orthodox, just like in their motherland.

9 Estonia was part of the USSR at the time.

${ }^{10}$ See https://arhiiv.err.ee/seeria/esivanemate-vaimuvara/haridus/69/date-desc/koik, last accessed on 16 January 2020.

${ }^{11}$ See https://arhiiv.err.ee/otsi/brauser, last accessed on 16 January 2020.

${ }^{12}$ See https://arhiiv.err.ee/seeria/paar-palvid/kultuur/31/title-asc/2, last accessed on 16 January 2020.

${ }^{13}$ It has also been published under the names of Petrogradi Teataja, Pealinna Teataja, Vabadus, Edasi, Eesti.

${ }^{14}$ See https://kultuuriseltsid.ee/uudised/2017/peterburi-teataja-taassund/, last accessed on 16 January 2020.

${ }^{15}$ See www.folklore.ee/estonka, last accessed on 17 January 2020.

${ }^{16}$ Street riots that took place in Tallinn and elsewhere on 26-29 April 2007. The unrest was caused by the relocation of the Bronze Soldier monument, erected on Tõnismägi Hill in memory of the Red Army soldiers, to the Defence Forces cemetery in Tallinn. 


\section{REFERENCES}

Apo, Satu 1993. Kirjoittavat kertojat. Teemakirjoittaminen - folkloristiikan "näkymätön" ainestonhankintamenetelmä. [Writing Narrators: Theme-Writing - An "Invisible" Method of Material Acquisition in Folklore.] Elias, Vol. 4, pp. 12-15.

Carpenter, Inta Gale 2011. Staged History in a Siberian Village. In: Ieva Garda Rozenberga \& Mara Zirnite (eds.) Oral History: Migration and Local Identities. Riga: University of Latvia, pp. 34-53. Available at https://dom.lndb.lv/data/obj/ file/185282.pdf, last accessed on 21 January 2020.

Clifford, James 1986. Introduction: Partial Truths. In: James Clifford \& George E. Marcus (eds.) Writing Culture: The Poetics and Politics of Ethnography. (A School of American Research Advanced Seminar.) Berkeley \& Los Angeles \& London: University of California Press, pp. 1-26.

Eesti 2002 = Eesti Draamateatri trupp sõitis Siberisse. [The Estonian Drama Theatre Went to Siberia.] Postimees. Kultuur, 15 April. Available at https://kultuur. postimees.ee/1933063/eesti-draamateatri-trupp-soitis-siberisse, last accessed on 28 January 2020.

Gonoshilov, Viktor 1998. Roditeli estontsy, deti - russkie. [Estonian Parents, Russian Kids.] Omskii Vestnik, 19 November, p. 8.

Haug, Tarmo 1991. Savisaar siberlastel meeles. [Savisaar in the Recollections of Siberian Estonians.] Liivimaa Kroonika, 29 August.

Heinla, Eve 2000. Piret Toomet sõitis Siberisse eesti keelt õpetama. [Piret Toomet Went to Siberia to Teach Estonian.] Õhtuleht, 24 September. Available at https://www. ohtuleht.ee/96765/piret-toomet-soitis-siberisse-eesti-keelt-opetama, last accessed on 28 January 2020.

Heinla, Eve 2008. Vagun nr. 28: kaheksa ööd ratastel. [Coach No. 28: Eight Nights on the Wheels.] Õhtuleht, 27 September. Available at https://naisteleht.ohtuleht. ee/297608/vagun-nr-28-kaheksa-ood-ratastel, last accessed on 5 February 2020.

Herkül, Kadi 2018. Siberi lugude latvu pidi. Draamateatri uuslavastuse arvustus. [Along the Treetops of Siberian Stories. Theatre Review.] Postimees. Kultuur, 9 April. Available at https://kultuur.postimees.ee/4464679/siberi-lugude-latvu-pidi, last accessed on 21 January 2020.

Hint, Madis 1998. Siberi eestlased on maetud unustusse. [Siberian Estonians Have Fallen into Oblivion.] Eesti Päevaleht, 14 December, p. 5. Available at https:// epl.delfi.ee/valismaa/siberi-eestlased-on-maetud-unustusse?id=50765926, last accessed on 16 January 2020.

Jordan, Arthur 1997. Vzgliad iz Tsvetnopol'e. [A Glimpse of Tsvetnopolye.] Ihre Zeitung, 19 May, p. 4.

Jürgenson, Aivar 2015. Etniline ja rahvuslik: Etnokultuurilistest protsessidest eesti idadiasporaas. [Ethnic and National: Ethnocultural Processes in the Estonian Eastern Diaspora.] Acta Historica Tallinnensia, Vol. 21, No. 1, pp. 23-50. DOI: $10.3176 /$ hist.2015.1.02.

Käänik, Kaspar 2008. Siberis jäi Narva küla vee alla. [In Siberia a Village Called Narva is Flooded.] Õhtuleht, 23 November. Available at https://www.ohtuleht.ee/305474/ siberis-jai-narva-kula-vee-alla, last accessed on 28 January 2020. 
Kalkun, Andreas \& Korb, Anu (comps.) 2012. Siberi setode laulud. Helisalvestusi Eesti Rahvaluule Arhiivist 7. [Songs of Siberian Seto. Recordings from the Estonian Folklore Archives.] Tartu: Eesti Kirjandusmuuseum.

Kirss, Tiina (comp.) 2006. Rändlindude pesad: Eestlaste elulood võorrsil. [Nests of Migratory Birds: Estonians' Life Stories Abroad.] Tartu: Eesti Kirjandusmuuseum.

Kistner, T. 2001. Vse, chto serdtsu dorogo. [All That Is Dear to the Heart.] Ihre Zeitung, 14 December, p. 5.

Korb, Anu 1997. Konverents ja ümarlaud kaimudest. [A Conference and Roundtable on Kindred Peoples.] Sirp, 26 September, p. 18. Available at https://dea.digar.ee/ cgi-bin/dea? a=d\&d=sirp19970926.1.18, last accessed on 22 January 2020.

Korb, Anu (comp.) 2005. Siberi eestlaste laulud. Helisalvestusi Eesti Rahvaluule Arhiivist 5. [Songs of Siberian Estonians. Recordings from the Estonian Folklore Archives.] Tartu: Eesti Kirjandusmuuseum.

Korb, Anu (comp.) 2010. Siberi eestlaste elud ja lood. Eesti asundused V. [The Lives and Stories of Siberian Estonians. Estonian Settlements.] Tartu: EKM Teaduskirjastus.

Kõresaar, Ene 2003. Eluloolisest käsitlusviisist Eesti kultuuriteaduses. [On Biographical Approach in Estonian Cultural Studies.] In: Tiiu Jaago (ed.) Pärimus ja tõlgendus: Artikleid folkloristika ja etnoloogia teooria, meetodite ning uurimispraktika alalt. Tartu: Tartu Ülikooli Kirjastus, pp. 61-76.

Kõresaar, Ene 2005. Elu ideoloogiad: Kollektiivne mälu ja autobiograafiline minevikutõlgendus eestlaste elulugudes. [Ideologies of Life: Collective Memory and Autobiographical Meaning-Making of the Past in Estonian Life Stories.] Tartu: Eesti Rahva Muuseum.

Kulu, Hill 1997. Eestlaste tagasiränne 1940-1989 Lääne-Siberist pärit eestlaste näitel. [Estonians' Remigration in 1940-1989: The Case of West-Siberian Estonians.] Tartu: Tartu Ülikooli Kirjastus.

Laasik, Andres 2001. Siberi opetaja tõde. [The Truth of a Siberian Teacher.] Eesti Päevaleht, 3 September, p. 11. Available at https://epl.delfi.ee/meelelahutus/siberiopetaja-tode?id=50808292, last accessed on 22 January 2020.

Laisaar, Väino 2016. $4 x 4$ reisid: Elu läbi kolme silma. [4x4 Travels: Life through Three Eyes.] Tallinn: Helios Kirjastus.

Liebkind, Karmela 1988. Me ja muukalaiset: Ryhmärajat ihmisten suhteissa. [Me and the Strangers: Group Boundaries in Human Relationships.] Helsinki: Gaudeamus.

Meomuttel, Jüri 1900. Eesti asunikud laialises Vene riigis: Esimene katse sõnumid kõikide Eesti asunduste üle tuua. [Estonian Settlers in the Great Russian Empire: The First Attempt to Spread News about All Estonian Settlements.] Jurjew: Postimehe Trükikoja Kirjastus. Available at https://ida.aule.ee/raamatud/meomuttel_orig. pdf, last accessed on 22 January 2020.

Nigol, August 1918. Eesti asundused ja asupaigad Venemaal. Teine katse sõnumid kõikide Eesti asunduste üle tuua ja esimene katse üleüldist korraldust luua asunduste jaoks. [Estonian Settlements and Places of Residence in Russia: The Second Attempt to Spread News about All Estonian Settlements and the First Attempt to Organize Settlements.] Eesti Kirjanduse Seltsi Kodumaa Tundmaõppimise Toimekonna toimetused nr. 1. Tartu: Eesti Kirjastuse-Ühisuse "Postimehe" trükk. Available at https://ida.aule.ee/raamatud/nigol1918_orig.pdf, last accessed on 22 January 2020. 
Olson, Laura J. 2004. Performing Russia: Folk Revival and Russian Identity. London \& New York: RoutledgeCurzon.

Peltonen, Ulla-Maija 1996. Punakapinan muistot: Tutkimus työväen muistelukerronnan muotoutumisesta vuoden 1918jälkeen. [Memories from the Red Rebellion: A Study of the Shaping of the Workers' Reminiscences after 1918.] Helsinki: Suomalaisen Kirjallisuuden Seura.

Pettai, Vello 2007. The Construction of State Identity and Its Legacies: Legal Restorationism in Estonia. Ab Imperio, Vol. 3, pp. 403-426. https://doi.org/10.1353/ imp.2007.0022.

Piho, Mare 2002. Setude ümberasumisest külmale maale. [The Migration of the Setu People into the Land of Cold.] In: Jüri Viikberg (comp.) Krimmi kogumik I: Konverentsi "140 aastat eestlust Krimmis" ettekanded (09.-10.09.2001, Beregove, Ukraina). Tallinn: Eesti Keele Sihtasutus, pp. 171-185.

Piirsalu, Jaanus 2008. Veidemann: Venemaa eestlased vääriksid rohkem tähelepanu. [Veidemann: Estonians in Russia Would Deserve More Attention.] Eesti Päevaleht, 2 August. Available at https://epl.delfi.ee/valismaa/veidemann-venemaa-eestlasedvaariksid-rohkem-tahelepanu?id=51137722, last accessed on 22 January 2020.

Portelli, Alessandro 2000 [1998]. What Makes Oral History Different. In: R. Perks \& A. Thompson (eds.) The Oral History Reader. London \& New York: Routledge, pp. 63-74.

Pöysä, Jyrki 2009. Kogumisvõistlused pärimusliku ajaloo uurimises. [Memoir Writing Competitions in Oral History Research.] Mäetagused, Vol. 43, pp. 39-60. http:// dx.doi.org/10.7592/MT2009.43.poysa.

Roemmich, Heinrich 1978. Die evangelisch-lutherische Kirche in Russland in Vergangenheit und Gegenwart. In: Joseph Schnurr (comp.) Die Kirchen und das religiöse Leben der Russlanddeutschen: Evangelischer Teil. Stuttgart: AER Verlag, pp. 1-63.

Ryan, Ellen B. 1979. Why Do Low-Prestige Language Varieties Persist? In: H. Giles \& R.N. St. Clair (eds.) Language and Social Psychology. Oxford: University Park Press, pp. 145-157.

Schudson, Michael 1997. Lives, Laws, and Language: Commemorative versus NonCommemorative Forms of Effective Public Memory. The Communication Review, Vol. 2, No. 1, pp. 3-17. https://doi.org/10.1080/10714429709368547.

Slezkine, Yuri 2012. NSVL kui ühiskorter ehk kuidas sotsialistlik riik etnilist eristumist edendas. [The USSR as a Joint Apartment or How the Socialist State Performed Ethnic Polarization.] Vikerkaar, No. 10/11, pp. 117-136; No. 12, pp. 76-101.

Suursaadik 2016 = Suursaadik Venemaal ja saadik Aadu Must külastasid Siberis elavaid Eesti kogukondi. [Ambassador in Russia and Parliament Member Aadu Must Visited the Estonian Communities.] Delfi.ee, 28 May. Available at https:// www.delfi.ee/news/paevauudised/eesti/suursaadik-venemaal-ja-saadik-aadumust-kulastasid-siberis-elavaid-eesti-kogukondi?id=74661315, last accessed on 5 February 2020.

Tammaru, Tiit 1999. Venelased Eestis: ränne ja kohanemine. [Russians in Estonia: Migration and Adaptation.] Tallinn: Sisekaitseakadeemia.

Tõnurist, Igor 1966. Etnograafilisi märkmeid Minussinski eestlastest ja lätlastest [Ethnographic Notes on Estonians and Latvians of the Minusinsk Region.] Manuscript. ERM, KV 195, pp. 108-166. 
Treufeldt, Indrek 2012. Ajakirjanduslik faktiloome erinevates ühiskondlikes tingimustes. [Construction of Journalistic Facts in Different Social Settings.] Tartu: Tartu Ülikooli Kirjastus. Available at https://www.digar.ee/arhiiv/et/raamatud/59678, last accessed on 22 January 2020.

Valitsusasutised 1934 = Valitsusasutiste tegevus 1918-1934. [Activity of Government Offices in 1918-1934.] Tallinn: Riigikantselei. Available at https://www.digar. ee/arhiiv/et/raamatud/43277, last accessed on 16 January 2020.

Venemaal 2011 = Venemaal Omski oblastis põles maha kolmandik Estonka külast. [In Omsk Oblast in Russia One Third of Estonka Village Burnt Down.] Postimees, 11 May. Available at https://maailm.postimees.ee/434278/venemaal-omskioblastis-poles-maha-kolmandik-estonka-kulast, last accessed on 28 January 2020.

Viikberg, Jüri 1988. Vanematest Eesti asundustest Siberis. [About Older Estonian Settlements in Siberia.] Keel ja Kirjandus, No. 5, pp. 284-288. Available at https:// www.digar.ee/arhiiv/et/perioodika/34920, last accessed on 22 January 2020.

Viikberg, Jüri 1997. Eesti külad Venemaal: keel ja identiteet. [Estonian Villages in Russia: Language and Identity.] In: Hill Kulu \& Katrin Metsis \& Tiit Tammaru (comps.) Eestlane olla ... Eesti keele ja kultuuri perspektiivid. Tartu: Tartu Ülikooli Kirjastus, pp. 28-52.

Viikberg, Jüri \& Vaba, Lembit 1984. Siberi põhjaeestlasi kõnetamas. [Communicating with Northern Estonians in Siberia.] Keel ja Kirjandus, No. 3, pp. 145-156; No. 4, pp. 210-223. Available at https://www.digar.ee/arhiiv/et/perioodika/34882 \& https:// www.digar.ee/arhiiv/et/perioodika/34883, both last accessed on 22 January 2020.

Zandberg, Eyal 2010. The Right to Tell the (Right) Story: Journalism, Authority and Memory. Media, Culture \& Society, Vol. 32, No. 1, pp. 5-24. https://doi. org/10.1177\%2F0163443709350095.

Zelizer, Barbie 2008. Why Memory's Work on Journalism Does Not Reflect Journalism's Work on Memory. Memory Studies, Vol. 1, No. 1, pp. 79-87. https://doi. org/10.1177\%2F1750698007083891.

\section{DOCUMENTARIES}

Drui, Heini 2001. Siberi õpetaja. [Teacher in Siberia.] Allfilm.

Korjus, Andres 2005. Võera maade sies. [In a Foreign Country.] Exitfilm.

Laiapea, Vahur 2013. Võidupäeva ootus Siberi Haida külas. [Expecting Victory Day in Khaydak Village in Siberia.] Ikoon.

Niglas, Liivo 2011. Puhkus Siberis. [Siberian Vacation.] F-Seitse.

Anu Korb $(\mathrm{PhD})$ is senior research fellow at the Estonian Folklore Archives of the Estonian Literary Museum, Estonia. Her main fields of research include folkloristic fieldwork theory, migration, oral history and folklore of Estonian communities in Siberia.

anu.korb@folklore.ee 